\title{
PEMBUATAN HERBAL SIAP SAJI DI MASA PANDEMI CoViD-19
}

\author{
Loth Botahala \\ Program Studi Kimia, Fakultas Matematika dan Ilmu Pengetahuan Alam, \\ Universitas Tribuana Kalabahi, Kabupaten Alor, Nusa Tenggara Timur, Indonesia 85817 \\ E-mail: botahala@gmail.com
}

\begin{abstract}
Abstrak
CoronaVirus Disease - 19 merupakan salah satu virus kelompok corona yang baru setelah MERS-Cov dan SARS-Cov-2. Virus ini dikabarkan awal pemunculannya di kota Wuhan, Cina. Gejala klinis yang timbul akibat penyakit ini sangat beragam, mulai dari flu biasa (batuk, pilek, nyeri tenggorokan, nyeri otot, nyeri kepala) hingga berkomplikasi berat (pneumonia). Di tengah pandemi virus Corona menjaga imunitas tubuh merupakan hal yang sangat penting. Daya tahan tubuh yang baik dapat mencegah terinfeksi dari virus Corona COVID-19. Banyak cara yang bisa dilakukan untuk meningkatkan imunitas tubuh, seperti berjemur, istirahat yang cukup, makan bergizi, hingga mengkonsumsi tumbuhan herbal. Salah satu cara untuk mencegah penyebaran CoViD-19 adalah selalu menjaga daya imun tubuh terhadap gejala-gejala klinisnya. Tujuan dari pengabdian masyarakat ini adalah untuk memberikan pengetahuan tentang pentingnya mengenal bahan-bahan alami yang dapat dijadikan herbal untuk mempertahankan daya tahan tubuh terhadap berbagai penyakit, terutama terhadap CoViD-19. Hasil Pengabdian kepada Masyarakat menunjukkan bahwa masyarakat Desa Maikang Kecamatan Alor Selatan Kabupaten Alor-NTT telah memperoleh pengetahuan tentang kandungan dan manfaat dari kunyit, jahe, dan gula merah sekaligus telah memperoleh pengetahuan tentang cara pembuatan herbal serta bersama menikmati hasil pembuatan herbal tersebut.
\end{abstract}

Kata kunci: CoViD-19, Herbal, Masyarakat, Desa, Maikang

\section{PENDAHULUAN}

CoronaVirus Disease - 19 merupakan salah satu virus kelompok corona yang baru setelah MERS-Cov dan SARS-Cov-2 (Ouassou dkk., 2020). Virus ini dapat menyebabkan gangguan pernafasan dan radang pada paru (Botahala, 2020). Virus ini dikabarkan awal pemunculannya di kota Wuhan, Cina, pada akhir Desember 2019 (Li dkk., 2020; Amalia dkk., 2020; Kramy, 2020; Susilo dkk., 2020). Virus ini menular dengan sangat cepat dan telah menyebar ke hampir semua negara, termasuk Indonesia (Botahala, 2020; Susilo dkk., 2020), hanya dalam waktu beberapa bulan. Penyakit ini disebabkan oleh infeksi Severe Acute Repository Syndrome CoronaVirus 2 (SARS-CoV-2) (Dhama dkk., 2020). Gejala klinis yang timbul akibat penyakit ini sangat beragam, mulai dari flu biasa (batuk, pilek, nyeri tenggorokan, nyeri otot, nyeri kepala) hingga berkomplikasi berat (pneumonia). Perkembangan virus ini masih sementara berlangsung (Botahala, 2020; Baharuddin, dkk., 2020; Ouassou dkk., 2020).

Jenis paling awal dari CoronaVirus baru yang oleh ilmuwan disebut Tipe A banyak ditemukan di Amerika Serikat dan Australia. Tipe ini adalah nenek moyang dari CoronaVirus dan punya hubungan dekat dengan CoronaVirus yang ditemukan pada kelelawar dan trenggiling. CoronaVirus Tipe B yang banyak ditemukan di Asia Timur berasal dari hasil mutasi Tipe A. Jenis Tipe B inilah yang genom pertamanya ditemukan di Wuhan dan kemudian penyakit ini menjadi mewabah. Sedangkan CoronaVirus yang menyebar di Hong Kong, Singapura, Korea, dan negaranegara Eropa sebagian besar adalah Tipe $\mathrm{C}$ (yang sama sekali tidak ditemukan di China) merupakan hasil mutasi dari Tipe B (Botahala, 2020; Li dkk., 2020).

Meskipun obat CoViD-19 mungkin membutuhkan waktu hingga 2021, beberapa obat yang sedang diuji sudah disetujui untuk indikasi antivirus lain atau sudah dalam pengujian lanjutan. Antivirus yang diuji seperti inhibitor RNA polimerase remdesivir, interferon beta, triazavirin, klorokuin, dan kombinasi lopinavir/ritonavir. Obat lain yang sedang diuji termasuk galidesivir, antivirus spektrum luas yang merupakan inhibitor RNA polimerase nukleosida, dan beberapa obat 
antivirus sudah dalam uji klinis. Karena memiliki efek terhadap koronavirus lainnya dan mode tindakan yang menunjukkan pengobatan tersebut mungkin efektif (Dhama dkk., 2020).

Di tengah pandemi virus Corona menjaga imunitas tubuh merupakan hal yang sangat penting. Daya tahan tubuh yang baik dapat mencegah terinfeksi dari virus Corona COVID-19. Banyak cara yang bisa dilakukan untuk meningkatkan imunitas tubuh, seperti berjemur, istirahat yang cukup, makan bergizi, hingga mengkonsumsi tumbuhan herbal. Indonesia dikenal memiliki beragam tumbuhan herbal yang baik dikonsumsi untuk kesehatan (Prasetya, 2020). Salah satu cara untuk mencegah penyebaran CoViD-19 adalah selalu menjaga daya imun tubuh terhadap gejalagejala klinisnya (Amalia dkk., 2020).

Organisasi pemerintahan terendah adalah desa yang memiliki hak istimewa dalam mengurus sendiri urusan daerahnya termasuk urusan masyarakatnya (Arma dkk., 2020). Sehingga kesejahteraan masyrakat desa menjadi tanggungjawab secara langsung oleh aparatur pemerintahan desa. Desa Maikang adalah salah satu desa di wilayah kabupaten Alor kecamatan Alor Selatan (Kande dkk., 2015). Berdasarkan hasil survey bahwa desa Maikang juga merupakan jalur transit perdagangan tradisional, karena terletak di perbatasan antara kecamatan Mataru, kecamatan Alor Tengah Utara, dan kecamatan Alor Selatan. Hal ini dapat berakibat kepada tertularnya masyarakat terhadap CoViD-19. Selain itu, pemanfaatan bahan-bahan alami sebagai herbal belum diketahui oleh masyarakat desa Maikang. Oleh karena itu tujuan kegiatan pengabdian kepada masyarakat ini adalah melakukan pelatihan pembuatan herbal siap saji dari bahan-bahan alami di sekitar masyarakat untuk meningkatkan daya tahan tubuh terhadap serangan penyakit, terutama terhadap CoViD-19.

Tanaman obat/herbal adalah jenis-jenis tanaman yang memiliki fungsi dan khasiat sebagai obat dan dipergunakan untuk penyembuhan atau pun mencegah datangnya berbagai penyakit (Sarno, 2019). Pemanfaatan tanaman obat/herbal belum banyak dilakukan oleh masyarakat. Hal tersebut disebabkan terbatasnya pengetahuan dan kemampuan masyarakat tentang pemanfaatan tanaman obat/herbal terutama untuk peningkatan daya imun (Sarno, 2019). Tujuan dari pengabdian masyarakat ini adalah untuk memberikan pengetahuan tentang pentingnya mengenal bahan-bahan alami yang dapat dijadikan herbal untuk mempertahankan daya tahan tubuh terhadap berbagai penyakit, terutama terhadap CoViD-19.

\section{METODE}

Bahan dan alat yang digunakan dalam kegiatan ini adalah kunyit, jahe, gula merah, air, panci, gelas, ceret, pisau, dan kelengkapan tungku tradisional. Tahapan pelaksanaan yang dilakukan pada kegiatan ini dengan Ceramah dan tanya jawab tentang kandungan senyawa dan mnfaat bahan-bahan herbal di sekitar masyarakat oleh narasumber Loth Botahala, S.T., M.Si.

Praktek pembuatan herbal dari bahan alami di sekitar masyarakat dengan prosedur kerja sebagai berikut:

a. Kunyit dan jahe masing-masing sebanyak 200 gram yang diambil dari halaman masyarakat desa Maikang, dibersihkan dengan air bersih. Kunyit diiris tipis-tipis sedangkan jahe dirajam kemudian kedua bahan tersebut direbus pada suhu sekitar $100^{\circ} \mathrm{C}$ selama 30 menit.

b. Setelah 30 menit, ditambahkan sebanyak 200 gram gula merah yang telah diiris tipis-tipis dan dibiarkan mendidih selama 10 menit.

c. Selanjutnya didinginkan dan disaring. Ramuan herbal siap disajikan untuk dikonsumsi.

\section{HASIL DAN PEMBAHASAN}

Kegiatan Pengabdian kepada Masyarakat ini dilaksanakan di Rumah Adat Desa Maikang kecamatan Alor Selatan kabupten Alor provinsi Nusa Tenggara Timur pada tanggal 26 Agustus 2020. Walaupun di antara kesibukan sebagai petani, warga masyarakat Desa Maikang tetap aktif mengikuti pelaksanaan kegiatan ini hingga akhir. 


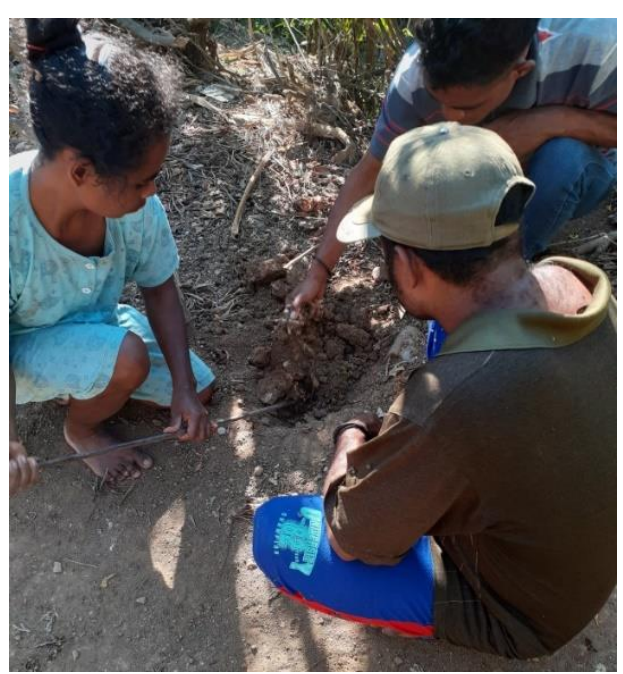

Gambar 1. Pengumpulan bahan herbal oleh masyarakat

Adapun manfat dari ramuan herbal tersebut di atas yang digunakan dalam kegiatan ini terhadap daya tahan tubuh dapat diuraikan sebagai berikut:

a. Kunyit banyak tumbuh di beberapa negara seperti Yunani, Cina, India, dan kawasan Asia Tenggara, sebagai rempah-rempah yang memiliki banyak khasiat (Wulandari dkk., 2018; Novelino, 2020). Kunyit mengandung curcumin yang merupakan senyawa fenolik. Kunyit dapat digunakan sebagai antiparasit, antiparasit, antiinfeksi, antioksidan, antimikroba, dan lain-lain (Wulandari dkk., 2018; Mubarak dkk., n.d.; Adrian, 2018; Wati dkk., 2017; Sarno, 2019).

b. Jahe merupakan tanaman herbal yang kerap dimanfaatkan untuk mengatasi berbagai kondisi, mulai dari mual, batuk, nyeri sendi, hingga nyeri akibat terapi kanker (Adrian, 2020). Kandungan senyawa metabolit sekunder pada tanaman jahe-jahean terutama golongan flavonoid, fenol, terpenoid dan minyak atsiri (Kaban dkk., 2016). Senyawa metabolit sekunder yang dihasilkan tumbuhan Zingiberaceae ini umumnya dapat meng-hambat pertumbuhan patogen yang merugikan kehidupan manusia, diantaranya bakteri Escherichia coli, Bacillus subtilis, Staphylococcus aureus, jamur Neurospora sp, Rhizopus sp. dan Penicillium sp. (Sari dkk., 2013). Jahe telah terbukti memiliki efek antimikrob, antifungal, antihelmintik, antioksidatif, antiimflamasi, antitumor, bersifat imunomodulatori, antilipidemic, bersifat analgesik, dan memiliki efek perlindungan terhadap saluran pencernaan (Harwati, 2012; Sarno, 2019).

c. Gula merah merupakan sebutan untuk gula yang dihasilkan dari nira pohon palma. Pohom palma sendiri ada beberapa jenis, namun yang biasa digunakan untuk bahan baku pembuatan gula merah adalah pohon aren (Arenga pinnata), nipah (Nypafruticans), dan siwalan (Borassua flabellifera) (Harismi \& Lestari, 2020). Gula merah mengandung energi sebesar 368 kilokalori, protein 0 gram, karbohidrat 95 gram, lemak 0 gram, kalsium 75 miligram, fosfor 35 miligram, dan zat besi 3 miligram. Selain itu didalam gula aren juga terkandung vitamin A sebanyak 0 IU, vitamin B1 0 miligram dan vitamin C 0 miligram. (Rahmah, Fani, 2016). Menurut Harismi \& Lestari (2020), manfaat gula merah adalah sebagai sumber energi, untuk meningkatkan daya tahan tubuh, dan dapat meredahkan sakit perut.

Setelah mendengarkan penjelasan dari narasumber, masyarakat dengan antusias mencari bahan-bahan (kunyit dan jahe) di pekarangan rumah sebagaimana terlihat pada Lampiran Gambar 1. Selanjutnya masyarakat dengan penuh semangat mengikuti proses pembuatan harbal siap saji (Gambar 2) hingga hasil yang siap dikonsumsi (Gambar 3). 

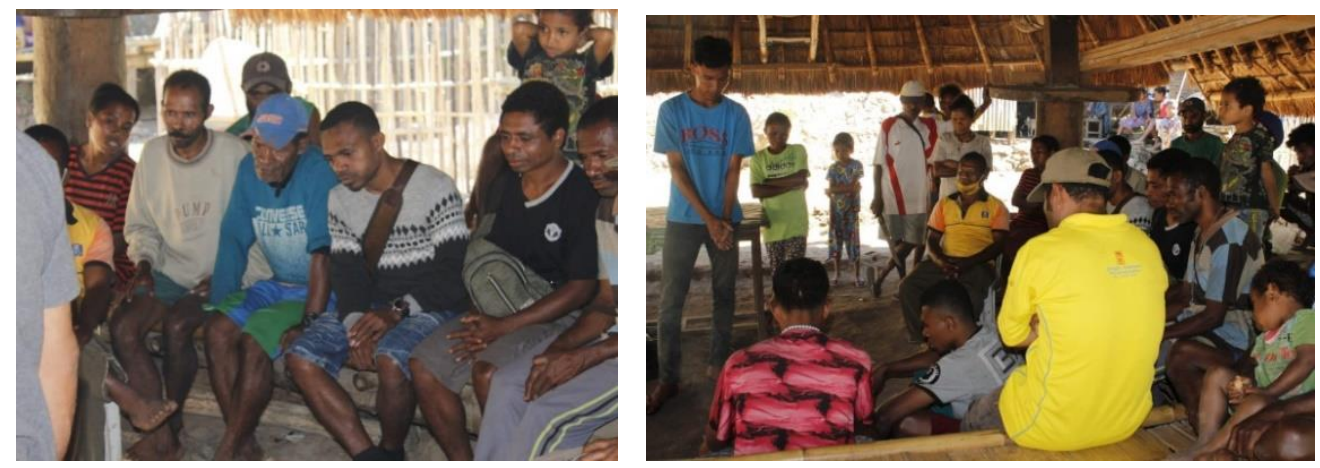

Gambar 2. Masyarakat sedang menyaksikan proses pembuatan herbal siap saji
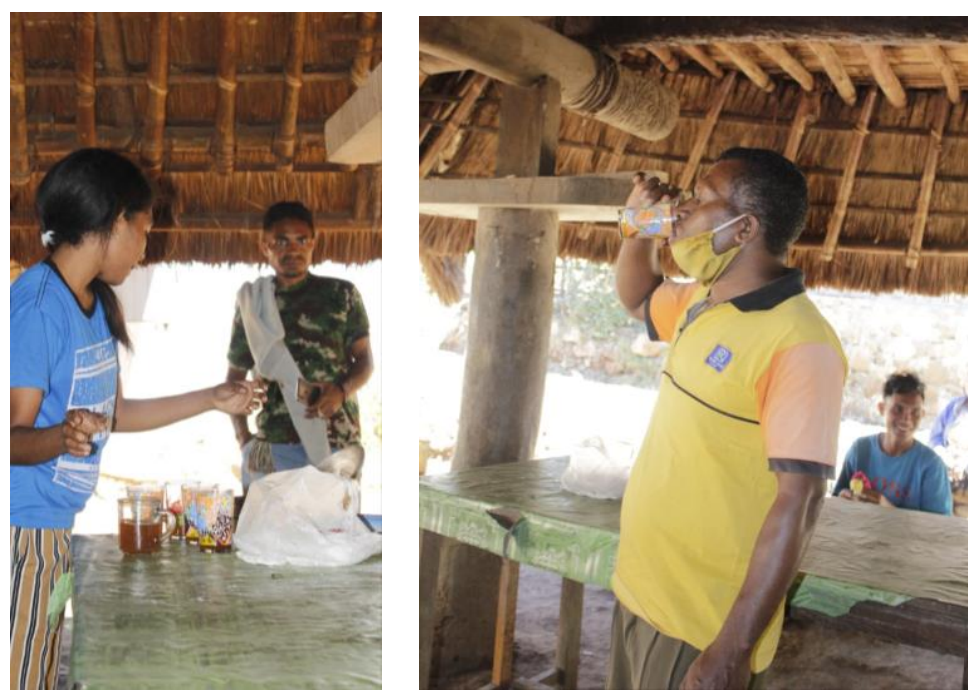

Gambar 3. a. Hasil herbal siap saji b. Herbal dikonsumsi

Akhir dari kegiatan pengabdian ini, sekretaris Desa Maikang mengucapkan terima kasih sekaligus menyatakan bahwa sesungguhnya di desa tersedia begitu banyak tanaman yang sesungguhnya sangat bermanfaat bagi masyarakat desa pada khususnya dan seluruh masyarakat pada umumnya jika ditopang dengan ilmu pengetahuan yang tepat.

\section{KESIMPULAN}

Adapun kesimpulan dari kegiatan ini adalah masyarakat Desa Maikang Kecamatan Alor Selatan Kabupaten Alor-NTT telah memperoleh pengetahuan tentang kandungan dan manfaat dari kunyit, jahe, dan gula merah sekaligus telah memperoleh pengetahuan tentang cara pembuatan herbal serta bersama menikmati hasil pembuatan herbal tersebut. Ucapan terima kasih kepada Yayasan Tribuana Alor dan Universitas Tribuana Kalabahi yang telah memberikan dukungan dalam pelaksanaan kegiatan "pengabdian kepada masyarakat" dari awal kegiatan hingga penerbitan artikel.

\section{DAFTAR PUSTAKA}

Adrian, K. (2018). Kebenaran Manfaat Kunyit Ditinjau dari Segi Medis. https://www.alodokter.com/kebenaran-manfaat-kunyit-ditinjau-dari-segi-medis

Adrian, K. (2020). Manfaat Jahe Bagi Kesehatan. In Tirto,id.

Amalia, L., irwan, I., \& Hiola, F. (2020). Analisis Gejala Klinis Dan Peningkatan Kekebalan Tubuh Untuk Mencegah Penyakit Covid-19. Jambura Journal of Health Sciences and Research, 2(2), 71-76. http://ejurnal.ung.ac.id/index.php/jjhsr/article/view/6134

Arma, N. A., Sopang, J., \& Jaffisa, T. (2020). Peningkatan Aparatur Desa Dalam Perencanaan Pembangunan Desa Di Desa Kota Rantang. RESWARA: Jurnal Pengabdian Kepada Masyarakat, $\quad$ 1(2), 91-95. 
http://jurnal.dharmawangsa.ac.id/index.php/reswara/article/view/573

Baharuddin, Andi, Iqbal; Massi, Muh, Nasrum; Marzuki; Thahir, Hasanuddin; Razak, Amran; Surungan, T. (2020). Merajut Asa Di Tengah Pandemi Covid-19 (Pandangan Akademisi UNHAS) - Google Buku. In Deepublish (1st ed.). Deepublish. https://books.google.co.id/books?hl=id\&lr=\&id=oQnyDwAAQBAJ\&oi=fnd\&pg=PP1\&dq=S uplemen+untuk+coronavirus+disease+2019\&ots=4g4Z6LHFZD\&sig=JwWeyOd7oFV6QNn $\mathrm{v}-\mathrm{XMdNSwn} 3 \_\mathrm{w} \&$ redir_esc $=\mathrm{y} \# \mathrm{v}=$ onepage $\& \mathrm{q} \& \mathrm{f}=\mathrm{false}$

Botahala, $\quad$ L. (2020). $\quad$ CoronaVirus 2019. https://lothbotahala.blogspot.com/2020/05/coronavirus-disease-2019.html

Dhama, K., Khan, S., Tiwari, R., Sircar, S., Bhat, S., Malik, Y. S., Singh, K. P., Chaicumpa, W., Bonilla-Aldana, D. K., \& Rodriguez-Morales, A. J. (2020). Coronavirus disease 2019COVID-19. Clinical Microbiology Reviews, 33(4), 1-48. https://doi.org/10.1128/CMR.00028-20

Harismi, A., \& Lestari, K. (2020). Manfaat Gula Merah untuk Kesehatan. https://www.sehatq.com/artikel/selain-memaniskan-makanan-ini-manfaat-gula-merah-untukkesehatan

Harwati, C. T. (2012). Khasiat Jahe Bagi Kesehatan Tubuh Manusia. Innofarm:Jurnal Inovasi Pertanian, 8(1), 54-61. http://ejurnal.unisri.ac.id/index.php/innofarm/article/view/226

Kaban, A. N., Daniel, \& Saleh, C. (2016). Uji Fitokimia, Toksisitas dan Aktivitas Antioksidan Fraksi n-heksan dan Etil Asetat terhadap Ekstrak Jahe Merah (Zingiber officinale var. amarum). Jurnal Kimia Mulawarman, 24-28. http://jurnal.kimia.fmipa.unmul.ac.id/index.php/JKM/article/view/259/274

Kande, F. A., Tausbele, Y., Heo, S. M., Djasibani, H. R., Gorang, A. F., Selly, A., Malaikosa, E., \& Botahala, L. (2015). Hasil Kajian Penetapan Kawasan Perdesaan di Kabupaten Alor (1st ed.). MedGraf Publisher. http://repo.untribkalabahi.ac.id/xmlui/handle/123456789/253

Kramy, P. (2020). Terapi Potensial Terkini Corona Virus Disease 2019 (Covid19). Cermin Dunia Kedokteran, 47(4), 297-298. http://103.13.36.125/index.php/CDK/article/view/389

Li, H., Liu, S.-M., Yu, X.-H., Tang, S.-L., Tang, C.-K., \& Rolain, J.-M. (2020). Coronavirus disease 2019 (COVID-19): current status and future perspectives. International Journal of Antimicrobial Agents, 55, 105951. https://doi.org/10.1016/j.ijantimicag.2020.105951

Mubarak, Z., Gani, Basri, A., \& Mutia. (n.d.). Daya Hambat Kunyit (Curcuma longa linn) Terhadap Pertumbuhan Candida albicans. Cakradonya Dent J, 11(1), 1-7.

Novelino, A. (2020). Jamu untuk Daya Tahan Tubuh: Dosis dan Cara Penyajian. https://www.cnnindonesia.com/gaya-hidup/20200526141217-255-506989/jamu-untuk-dayatahan-tubuh-dosis-dan-cara-penyajian

Ouassou, H., Kharchoufa, L., Bouhrim, M., Daoudi, N. E., Imtara, H., Bencheikh, N., Elbouzidi, A., \& Bnouham, M. (2020). The Pathogenesis of Coronavirus Disease 2019 (COVID-19): Evaluation and Prevention. In Journal of Immunology Research (Vol. 2020). Hindawi Limited. https://doi.org/10.1155/2020/1357983

Prasetya, J. (2020). Herbal yang Dianjurkan BPOM agar Imun Kuat di Masa New Normal. https://probatam.co/2020/05/27/herbal-yang-dianjurkan-bpom-agar-imun-kuat-di-masa-newnormal/

Rahmah, Fani, A. (2016). Pengaruh Penggunaan Jenis Gula Merah Dan Lama Fermentasi Terhadap Karakteristik Water Kefir. Universitas Pasundan Bandung.

Sari, K. I. P., Periadnadi, -, \& Nasir, N. (2013). Uji Antimikroba Ekstrak Segar Jahe-Jahean (Zingiberaceae) Terhadap Staphylococcus aureus, Escherichia coli dan Candida albicans. Jurnal Biologi UNAND, 2(1). http://jbioua.fmipa.unand.ac.id/index.php/jbioua/article/view/33

Sarno, S. (2019). Pemanfaatan Tanaman Obat (Biofarmaka) Sebagai Produk Unggulan Masyarakat Desa Depok Banjarnegara. ABDIMAS UNWAHAS, 4(2). https://doi.org/10.31942/abd.v4i2.3007

Susilo, A., Rumende, C. M., Pitoyo, C. W., Santoso, W. D., Yulianti, M., Herikurniawan, H., Sinto, R., Singh, G., Nainggolan, L., Nelwan, E. J., Chen, L. K., Widhani, A., Wijaya, E., Wicaksana, B., Maksum, M., Annisa, F., Jasirwan, C. O. M., \& Yunihastuti, E. (2020). Coronavirus Disease 2019: Tinjauan Literatur Terkini. Jurnal Penyakit Dalam Indonesia, 7(1), 45. https://doi.org/10.7454/jpdi.v7i1.415 
Wati, I., Musadi, M. R., Khumaira, N. S., \& Amelia, A. R. (2017). Pengaruh Konsentrasi Pelarut, Waktu Ekstraksi, Dan Nisbah Bahan Baku Dengan Pelarut Terhadap Ekstraksi Kunyit Kuning (Curcuma longa L.). Jurnal ITEKIMA, 2(1), 52-60.

Wulandari, A., Rodiyani, \& Sari, R. D. P. (2018). Pengaruh Pemberian Ekstrak Kunyit ( Curcuma longa linn ) dalam Mengatasi Dismenorea [Effect of Turmeric Extract (Curcuma longa linn) in Reducing Dysmenorrhoea]. Majority, 7(2), 193-197. 